\title{
Relationship between the probability of veterinary-diagnosed bovine mastitis occurring and farm management risk factors on small dairy farms in Austria
}

\author{
Clair L. Firth, ${ }^{1 *}$ Christian Laubichler, ${ }^{2}$ Corina Schleicher, ${ }^{2}$ Klemens Fuchs, ${ }^{2}$ Annemarie Käsbohrer, ${ }^{1}$ \\ Christa Egger-Danner, ${ }^{3}$ Josef Köfer, ${ }^{1}$ and Walter Obritzhauser ${ }^{1,4}$ \\ ${ }^{1}$ Institute of Veterinary Public Health, University of Veterinary Medicine, 1210, Vienna, Austria \\ ${ }^{2}$ Data, Statistics and Risk Assessment, Austrian Agency for Health and Food Safety (AGES), 8010, Graz, Austria \\ ${ }^{3}$ ZuchtData GmbH, 1200, Vienna, Austria \\ ${ }^{4}$ Veterinary Practice, Randweg 4, Parschlug, 8605, Styria, Austria
}

\section{ABSTRACT}

Bovine mastitis is the most frequently reported disease among dairy cows worldwide. Treatment of udder disease often involves the use of antimicrobial substances, which is difficult to justify with respect to their possible effect on the development and spread of antimicrobial resistance. Prevention of udder disease is therefore always preferable to treatment. The study presented here statistically analyzed the probability of mastitis occurring during 3,049 lactation periods on 208 farms and attempted to ascertain which on-farm management factors contributed to the occurrence of this udder disease in Austria. Farm management was assessed via online surveys completed by 211 farmers $(211 / 251$; response rate $=84.1 \%)$ as well as national milk performance recorders observing milking technique and herd veterinarians evaluating farm hygiene levels. Veterinary treatment records were used as a basis for mastitis reporting. The analysis was carried out using a generalized linear mixed model. The study population was not randomized but was part of a larger observational study. More than three fourths of the study farms were run conventionally, and the remainder were organic. Freestalls (and straw yards) made up $66 \%$ of the study population, and $34 \%$ of farms had tiestalls. Herd size ranged from 8 to 94 dairy cows (mean = $26.9 ;$ median $=21)$, with the most common breed $(74 \%$ of all cows) being dual-purpose Simmental (Austrian Fleckvieh). A mastitis risk of $14.4 \%$ was reported via veterinary treatment records. The following factors were shown to be associated with a reduction in the risk of mastitis occurring: regular access to pasture (odds ratio, $\mathrm{OR}=0.73$ ), automatic milking machine shut-off (OR 0.67), and access to feed immediately after milking $(\mathrm{OR}=0.43)$. Detrimental effects, which

Received September 6, 2018.

Accepted January 20, 2019.

*Corresponding author: clair.firth@vetmeduni.ac.at were likely to increase the probability of mastitis occurring, included lactation number $(\mathrm{OR}=1.18)$, farming part time $(\mathrm{OR}=1.55)$, and udders on the farm being classed by herd veterinarians as medium to severely soiled $(\mathrm{OR}=1.47)$. The study presented here was able to confirm several management factors recommended to reduce the probability of mastitis occurring during a cow's lactation period, with particular relevance for the small dairy herds common to Austria.

Key words: mastitis, farm management, generalized linear mixed model, udder disease

\section{INTRODUCTION}

Bovine mastitis is an extremely important disease of dairy cows from an economic, societal, public health, and ethical point of view. The economic costs of mastitis are difficult to quantify; however, a recent Dutch study estimated that average production losses (including reduced milk yield, discarded milk, and culls) amounted to approximately $€ 120 /$ cow per year, with an additional $€ 120 /$ cow per year spent on preventive measures (van Soest et al., 2016). As such, mastitis is a disease that nobody can afford to ignore.

Hand in hand with animal health, farm hygiene, and the production of high-quality dairy products, animal welfare is also extremely important to both farmers and consumers. Ensuring that high-yielding dairy cows are adequately fed and have the freedom to exhibit normal and natural behavior in a comfortable environment is essential, as is the prevention of disease. Therefore, farmers as well as veterinarians continue to play an indispensable role in the maintenance of a healthy herd.

Management and hygiene of the farm have long been known to be essential in ensuring udder health, with hygienic milking routines being particularly important. A standardized plan for reducing new mammary infections was first developed at the National Institute for Research in Dairying (Reading, UK) and published in 1966. This 5-point plan included the rapid identifica- 
tion and treatment of clinical mastitis cases, routine whole-herd (blanket) antimicrobial dry cow therapy, postmilking teat disinfection, culling of chronically infected cows, and routine maintenance of the milking machine (Neave et al., 1966).

Today, in the face of increasing antimicrobial resistance and the need for more prudent use of antimicrobials, veterinarians are attempting to reduce the use of blanket dry cow therapy and be more selective in their use of antimicrobial agents at drying off. However, the remaining points are still relevant, and effective farm management, on-farm hygiene, and biosecurity are critical to ensure udder health.

Dairy farms in Austria, as in Switzerland and in Alpine regions of Italy, are often relatively small (on average around 20 dairy cows) compared with the European average herd size (Busato et al., 2000; Corazzin et al., 2010; Pothmann et al., 2014). This leads to specific differences between Alpine farms and larger, more intensive farms in the lowland areas of Europe and North America. For example, dairy farmers often work elsewhere, obtaining more than $50 \%$ of their incomes from employment off-farm, leaving less time for stock management compared with full-time farmers (Pothmann et al., 2014). Previous studies in Austria have shown that more than $88 \%$ of dairy farmers feel that mastitis is a problem on their farm (Pothmann et al., 2014); however, the vast majority of studies investigating the influence of management risk factors on the occurrence of mastitis have concentrated on much larger conventional herds or small, purely organic ones.

The primary aim of this study was to analyze the relationship between the probability of mastitis occurring in a cow within 1 lactation period (LP) and specific risk factors in farm management under the conditions of small dairy farms in Austria. To this end, we collected data pertinent to farmers, veterinarians, and those with a commercial interest in the dairy industry and aimed to provide relevant suggestions and recommendations to improve dairy cow welfare and milk production.

\section{MATERIALS AND METHODS}

In this study, 251 Austrian dairy farmers agreed to report cases of mastitis and provide milk samples from all cows exhibiting mastitis signs over a period of 1 calendar year. This survey was carried out as part of the multidisciplinary project titled ADDA-Advancement of Dairying in Austria, comprising academic researchers, farmers, veterinarians, and representatives of the dairy industry.

In Austria, veterinarians have been required by law to document any diagnoses made on farm since 2002 regardless of whether they are notifiable livestock epidemics or merely mastitis cases (Egger-Danner et al., 2012). As part of the Health Monitoring in Cattle project, logistics for central data storage in conjunction with other production data were established in 2006 (Egger-Danner et al., 2012). As such, veterinary data were available that allowed the authors to assess the probability of mastitis occurring on these dairy farms. Both the farmers and respective national milk performance recorders were also asked to complete a farm management questionnaire to assess a variety of relevant factors, including milking technique, hygiene, production system, and biosecurity. Herd veterinarians were requested to assess overall farm hygiene.

\section{Study Population}

Veterinarians were initially contacted directly by the authors, and 18 practices agreed to take part in the survey. These veterinarians then carried out respondent-driven sampling (meaning that they were completely free to decide who to enroll; Gile and Handcock, 2010) and recruited farmers from their practice areas. The authors made no attempt to influence the veterinarians' choice of farmer. No restrictions were made concerning conventional or organic farmers, loose housing and freestalls or tiestalls, or alpine or valley farms. For study administration and logistical reasons of data collection, all veterinarians and dairy farmers were required to be enrolled in the Austrian Animal Health Service (German: Tiergesundheitsdienst), and the dairies also took part in the national milk performance recording scheme. Initially, 283 dairy farmers agreed to take part in the study; 251 of these signed an informed consent form and permitted the use of diagnostic and therapeutic data from their farms within the context of this study. Diagnosis and treatment records were collected between October 1, 2015, and September $30,2016$.

\section{Questionnaires}

Internet questionnaires were set up using the proprietary software SoGoSurvey (SoGo Survey Inc., Herndon, VA; www.sogosurvey.com). Questions ranged from multiple-choice, open, and semiclosed to closed. Some questions were mandatory and some were optional. The use of the online system allowed conditional branching to be used, whereby some questions were initially invisible and only appeared to the participant depending on their answer to the previous question. Three different questionnaires were sent via email to farmers, veterinarians, and national milk performance recorders.

Once the farmer had consented to data sharing via the informed consent form, farmers' email addresses 
Table 1. Subject areas covered by the questionnaires

\begin{tabular}{lc}
\hline & \\
Subject area & $\begin{array}{c}\text { Maximum no. } \\
\text { of questions }\end{array}$ \\
\hline (1) Farmer questionnaire & 2 \\
Education & 3 \\
Farm type & 13 \\
Housing systems and hygiene & 13 \\
Mastitis management/prevention/treatment & 8 \\
Milking/parlor equipment & 14 \\
Dry cow management & 6 \\
Animal health & 7 \\
Calf management & 13 \\
Feed and water & 4 \\
Foot health & 7 \\
Access to pasture or outdoor yards & 6 \\
Pest control and biosecurity & \\
(2) National milk performance recorder questionnaire & 3 \\
Hand hygiene at milking & 7 \\
Milking routine & 12 \\
Postmilking routine & 4 \\
Milking machine & 10 \\
Maintenance of parlor machinery & 4 \\
Cleanliness of parlor & 2 \\
Housing systems and hygiene 3 Herd veterinarian questionnaire & 10 \\
Most common mastitis pathogens & 4 \\
Most commonly used dry cow tubes & 3 \\
Use of teat sealants & 2 \\
Udder hygiene (using photographic scale) & 5 \\
Housing systems and hygiene & 1 \\
\hline & 4 \\
\hline
\end{tabular}

were provided by the local veterinarians from their practice records. The farmer questionnaire consisted of a maximum of 96 questions on farm type, housing systems and hygiene, dry cow management, mastitis management, calf management, feed and water, foot health, access to pasture or outdoor yards, pest control, and biosecurity (Table 1). If participants did not have access to the Internet or did not provide an email address, then paper versions were sent by mail with a prepaid return envelope enclosed, or the local veterinarian was requested to give a paper copy to the relevant farmer.

The national milk performance recorder (NMR) questionnaire was shorter, consisting of a maximum of 52 questions (Table 1), and was to be completed online by NMR employees who visited the study farms as part of their routine daily work. The NMR questionnaire concentrated primarily on milking technique and hygiene. It was considered that NMR employees were known to the farmers and were in an ideal position to observe regular milking practices without the bias sometimes caused when veterinarians or other external observers are present during milking. Herd veterinarians were asked to complete an online questionnaire (with a maximum of 19 questions) to assess hygiene and mastitis prevention measures carried out on each farm (Table 1). The herd veterinarian questionnaire also included a photographic scale of udder cleanliness to assist the respondents with their assessment of herd hygiene.

Questionnaire content and the overall study protocol were registered by the relevant ethics committees. The study was discussed and approved by the Institutional Ethics and Animal Welfare Committee of the University of Veterinary Medicine, Vienna (ref no. ETK$13 / 11 / 2015)$ in accordance with good scientific practice guidelines and national legislation. Furthermore, as the questionnaires required the collection of data relating to human subjects (e.g., level of education), these documents were also submitted to the Ethics Committee of the Medical University of Vienna. This ethics committee decided that an official decision on the present study was not required, in accordance with current Austrian legislation.

Before the data collection period, the questionnaires were tested for clarity and understanding on 2 members of each of their respective participant groups. A copy of the questionnaire (in German) can be obtained from the authors upon request. The questionnaire was sent individually to each farmer via email or mail in February 2016. Reminders were sent to nonresponders at approximately monthly intervals. Although the questionnaire itself was not completed anonymously because email addresses and agricultural holding numbers were attached to the results, any further analysis was anonymized. In an attempt to secure as many responses to the farmers' questionnaire as possible, a total of 5 email reminders were sent to each farmer. Furthermore, the enrolled veterinarians were requested to remind each farmer of their agreement to participate. The online collection period closed in November 2016.

\section{Data Sources}

Mastitis Diagnosis. Between October 1, 2015, and September 30, 2016, veterinary medicine dispensing and administration records for the enrolled dairy farms were collected from veterinary practice software (as previously described by Firth et al., 2017). These computerized records included standardized diagnosis codes (e.g., acute mastitis, chronic mastitis, teat injury), enabling an analysis of mastitis cases. In the present study, a diagnosis recorded as either acute or chronic mastitis was classed as a mastitis case.

A recent publication analyzing milk samples taken from this study population for bacteriological culture reported that $85.5 \%$ of the 647 cows from 166 dairy farms were sampled only once (Schabauer et al., 2018). Furthermore, $34.7 \%$ of milk samples from this study population were taken due to acute mastitis cases and 
$31.4 \%$ because of elevated SCC. Chronic mastitis cases made up only $0.1 \%$ of milk samples. No specific criteria for the diagnosis of mastitis cases were predefined by the authors. Instead, diagnoses were made by the herd veterinarian according to his or her clinical judgment based on, for example, altered California mastitis test results, swollen quarter, or altered milk consistency. Where milk samples were sent for bacteriological culture, clinical signs were also noted on the accompanying form (Schabauer et al., 2018).

Questionnaire Data. Data were exported to a Microsoft Excel spreadsheet (Microsoft Corp., Seattle, WA). Of 251 participating farmers, 235 had an active email address and 16 questionnaires were sent via mail to farmers who were not online. Responses received on paper were added verbatim to the online database by the first author. In all, 211 of 251 farmers completed the questionnaire. This corresponds to a response rate of 84.1\%. The following areas were analyzed according to answers given by the farmers, veterinarians, and NMR employees in response to the management questions: farm structure and procedures, milking equipment and procedures, farm hygiene, calf management, dry cow management, and mastitis prevention and detection.

Additional Farm Data. Milk production data, including ECM (4.0\% milk fat, $3.4 \%$ milk protein), calving and insemination data, cattle breed, and herd size, were provided for all farms included in the study by a subsidiary of the Federation of Austrian Cattle Breeders (ZAR), "ZuchtData," which is responsible for the central cattle database (German: Rinderdatenverbund) where data from performance recording, meat and milk marketing, and health monitoring as well as herdbook data are stored and processed.

\section{Statistical Analysis}

For statistical analysis, a cow was classed as having mastitis in that LP if a diagnosis of acute or chronic mastitis was reported at least once within the corresponding LP. As expected, some LP did not fit exactly within the study period. For this reason, the following inclusion criteria were applied to the data to decide which LP should be included in the analysis. A minimum of 50 lactation days postpartum was required to ensure that at least 1 national milk performance recording visit took place. With respect to extended LP, only the first 305 lactation days postpartum were required to fall within the study period from October 1, 2015, to September 30, 2016. For practical reasons, tolerance periods of 30 lactation days before October 1, 2015, and 90 lactation days after September 30, 2016, were also included in this definition of an LP. A total of 3,049 LP on 208 farms fulfilled these criteria and were included in the analysis. Descriptive analyses of all possible explanatory variables (questionnaire and additional farm data) collected were done using SPSS statistical software (IBM Corp., Armonk, NY).

To analyze the relationship between the probability of mastitis occurring in a particular cow during an LP and specific risk factors in farm management, a generalized linear mixed model (GLMM) was applied. The model was fitted under the assumption that the probability of mastitis in an LP may depend on cow- and farm-specific risk factors and additional, unobserved farm characteristics. Consequently, the probability of mastitis occurring in a cow cannot be considered to be statistically independent of the probabilities for other cows from the same farm. Therefore, the probability of mastitis occurring in LP $i$ was modeled with dependence of explanatory variables $x_{i j}=\left(x_{i j 1}, \ldots, x_{i j p}\right)$ and a random effect $b_{j}$ corresponding to the farm. Let $y_{i j}$ be the binary information if mastitis occurs within the cow's LP $i$ on farm $j$. The GLMM is then given by $y_{i j} / b_{j}$ $\sim \operatorname{Bernoulli}\left(\pi_{i j}\right)$, where

$$
\begin{aligned}
\operatorname{logit}\left(\pi_{i j}\right) & =\log \left(\frac{\pi_{i j}}{1-\pi_{i j}}\right)=\beta_{0}+x_{i j} \boldsymbol{\beta}+b_{j} \\
b_{j} \sim N\left(0, \sigma_{\text {farm }}^{2}\right), j & =1, \ldots, 208,
\end{aligned}
$$

with intercept $\beta_{0}$, the coefficient vector $\boldsymbol{\beta}$ corresponding to the $p$ explanatory variables, and the variance of the random effect $\sigma_{\text {farm }}^{2}$.

Due to the large number of (possibly also correlated) variables, a forward stepwise variable selection process was chosen to develop the final model. In particular, according to a 10 -times repeated 5 -fold cross-validation procedure, at each step the variable that provided the greatest additional improvement to the model was added. Thus, the mean squared error of the model is minimized and overfitting is avoided. More information on this technique can be found in Hastie et al. (2009). It is also important to note that particular attention was paid to the clinical meaningfulness of the model's coefficients and, before data cleaning and analysis, the dairy veterinarians among the authors discussed with the statistical authors which areas were clinically relevant for mastitis occurrence. As such, not all responses to the questionnaires were included in the variable selection process. Further details are provided in Supplemental Table S1 and Supplemental Figures S1 and S2 (https://doi.org/10.3168/jds.2018-15657).

Before building the model, obviously collinear sets of variables were determined so that once a particular variable was entered into the model the others were 
excluded from the subsequent steps. For instance, the inclusion of lactation number resulted in the deletion of age of dairy cow from the search tree. To assess potential multicollinearity during the stepwise modelbuilding process, we compared the covariates' coefficients, standard errors, and estimated correlations at each step. For the final model, we further calculated the variance inflation factors using the $\mathrm{R}$ package car (Fox and Weisberg, 2011). We did not observe any evidence of severe multicollinearity while building the model.

After including LP as a (linear) fixed effect in the model, we also tested for a quadratic effect of the LP using the cross-validation approach. We did not observe any improvement in the model by doing so. Note that we did not investigate interactions of the main effects. Testing all (bivariate) interactions of all possible fixed effects would have been too extensive. We also avoided testing specific predefined interactions. Theoretically, a multiple of the sample size is required to detect an interaction with the same statistical power as a main effect. The current study was, however, not designed with this issue in mind and we did not want to risk that potential results were merely statistical noise. It is also important to note that the GLMM includes a random farm effect. Therefore, there is a low risk that the final model suffers severely from any missing farm-specific characteristics (i.e., main effects as well as interactions).

The $P$-values shown were calculated by likelihood ratio tests, and parametric bootstrapping was used to derive confidence intervals on the parameter estimates. The GLMM was implemented in $\mathrm{R}$ version 3.3.2 ( $\mathrm{R}$ Core Team, 2016) using the package lme4 (Bates et al., 2015).

\section{RESULTS}

\section{Lactation Periods}

A total of 3,049 LP on 208 farms fit within the predefined criteria. These 208 farms were determined to have between 1 and 64 qualifying LP during the study, with a mean of $14.8 \mathrm{LP}$ per farm. A total of 66 farms had fewer than 15 dairy cows in the herd (Figure 1), and 16 farms had fewer than 5 qualifying LP during the observational period. Mastitis occurred at least once during 439 LP, giving a mastitis occurrence risk of $14.4 \%$. The mean mastitis occurrence risk per farm was $14.9 \%$, with a median $11.7 \%$ (range $=0-75.0 \%$ ).

\section{Farm Management Factors}

Farm Demographics. Of the 211 farmers who responded to the questionnaire, the vast majority farmed conventionally (164/211, $77.7 \%$ ); an additional 19.9\% of holdings were managed according to organic criteria, and the remaining $2.4 \%$ of the farms included in the study were classified as other systems (e.g., in transition from conventional to organic production). Most farms $(152 / 211,72.0 \%)$ were run as full-time enterprises; on the remaining farms, the farmers $(59 / 211$, $28.0 \%$ ) earned less than $50 \%$ of their household income from the farm and worked at least part time elsewhere (Table 2).

The distribution of cattle and dairy cow herd size by farm is shown in Figure 1, and herd production parameters are provided in Table 3. Standardized SCC from national milk performance recordings based on 305-d LP were available for all farms.

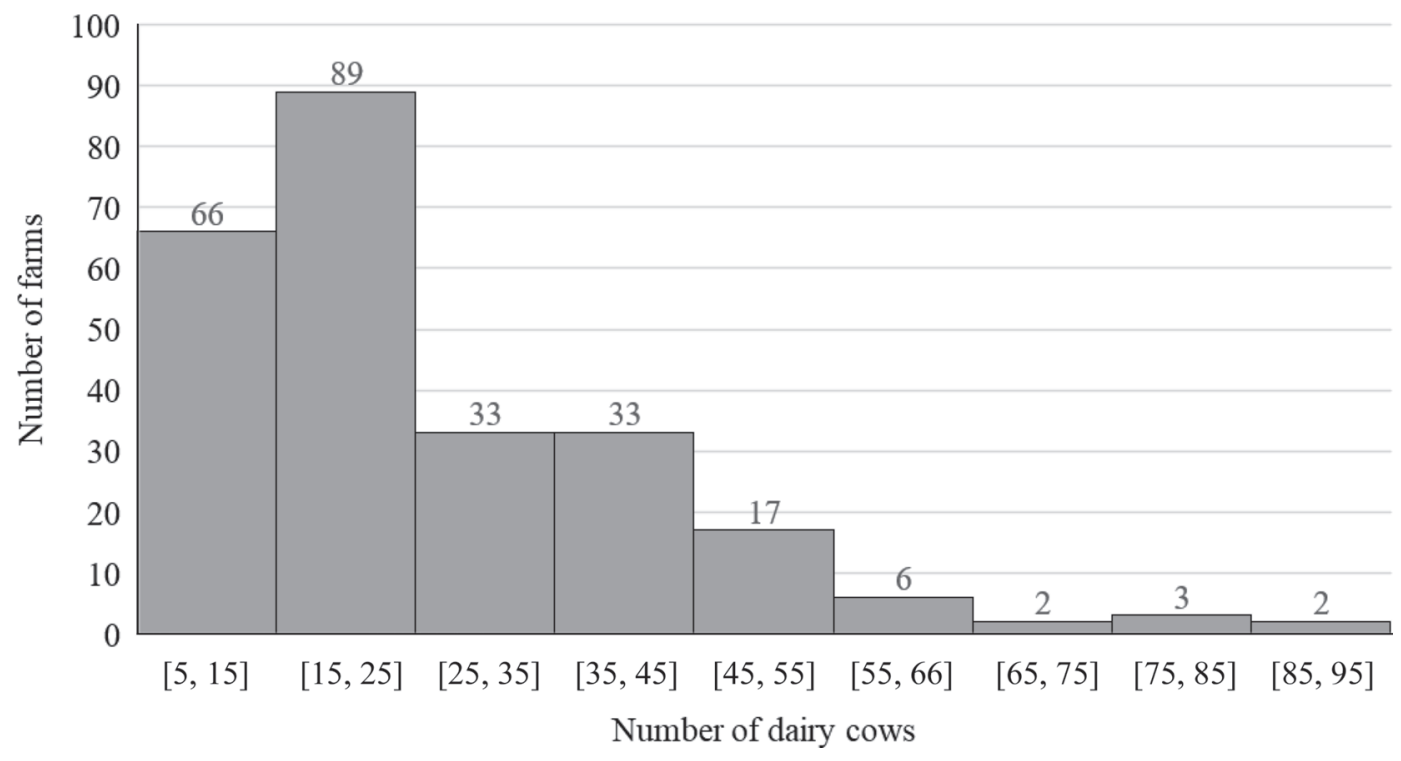

Figure 1. Dairy cow herd size distribution for farms in the study population $(\mathrm{n}=251)$. 
Table 2. Farm management and housing systems based on farmer responses $[\text { no. }(\%) ; \mathrm{n}=211]^{1}$

\begin{tabular}{lccc}
\hline Item & $\begin{array}{c}\text { Full-time farmers } \\
(\mathrm{n}=152)\end{array}$ & $\begin{array}{c}\text { Part-time farmers } \\
(\mathrm{n}=59)\end{array}$ & Total \\
\hline Management & $117(77.0)$ & $47(79.7)$ & $164(77.7)$ \\
$\quad$ Conventional & $31(20.4)$ & $11(18.6)$ & $42(19.9)$ \\
Organic & $4(2.6)$ & $1(1.7)$ & $5(2.4)$ \\
$\quad$ Other (e.g., converting) & $44(28.9)$ & $28(47.5)$ & $72(34.1)$ \\
Housing system & $108(71.0)$ & $31(52.5)$ & $139(65.9)$ \\
$\quad$ Tiestalls &
\end{tabular}

${ }^{1}$ Included in the variable selection process of the generalized linear mixed model.

A total of $34.1 \%$ of farms housed their dairy cows in tiestalls, and $65.9 \%$ used a variety of freestall and straw-yard systems (Table 2). Freestalls were more common than tiestalls among full-time farmers.

The majority $(77 / 87,88.5 \%)$ of farms with tiestalls milked in the barn via a vacuum pipeline system, whereas milking parlors were commonly used in freestall systems $(137 / 163,84.0 \%)$. Out of 250 farms observed in this study, a total of $12(4.8 \%)$ had automated milking systems and $10(4.0 \%)$ milked directly into a bucket and did not have any other kind of milking system.

The vast majority $(73.9 \%, 4,694 / 6,353)$ of the dairy cows included in the study were of the Simmental (Austrian Fleckvieh) breed, with a further 10.9\% $(693 / 6,353)$ of cows being Brown Swiss (Braunvieh). Holstein-Friesians made up only $12.7 \%(807 / 6,353)$ of the total dairy cow population in this study, which is typical for Austrian dairy production. Almost $30 \%$ of cows included in this observational study were primiparous, and the occurrence of mastitis increased with age and lactation number, as shown in Figure 2.

Mastitis Detection and Prevention Measures. A total of 115/211 (54.5\%) farmers reported that they regularly sent milk samples for bacteriological culturing in cases of mastitis. In addition, $12.8 \%$ of farmers required routine pre-drying off checks (i.e., bacteriological culture; Table 4). Blanket antimicrobial dry cow therapy was reported by $47.4 \%$ of farmers. When divided by production system, blanket dry cow therapy was carried out on $56 \%$ of conventional farms and only $18 \%$ of organic farms.
Milking Technique. According to the responses given by the national milk recorders $(\mathrm{n}=250)$, the milking machine had an automatic shut-off built in on the vast majority of farms with a milking parlor $(104 / 137,75.9 \%)$ and just over half of farms milking via a vacuum line system $(48 / 91,52.7 \%)$. In the herd veterinarians' experience of the study farms, cows' udders were reported to be moderately to extremely soiled before milking on 176/250 (70.4\%) farms. With respect to housing system, udders were reported to be moderately to severely soiled on $23.6 \%$ of farms with tiestalls compared with $13.8 \%$ of farms with freestalls. This difference was not found to be statistically significant in the chi-squared test $(P=0.072)$.

General Farm Management. On the vast majority of farms $(199 / 211,94.3 \%)$, cows were fed immediately after milking, and feeding space for all cows to eat simultaneously was available on $187 / 211$ (88.6\%) farms. Cows had regular access to pasture on $57.8 \%$ $(122 / 211)$ of farms. There was no evidence of a statistical association between cows given regular access to pasture and the presence of moderately to extremely soiled udders on farm (Pearson chi-squared test with Yate's continuity correction, $P=0.52$ ).

\section{GLMM}

According to the results of the variable selection process, the cow's current lactation number, farm management (data on whether the farm is run full time or part time, access to pasture, feeding after milking and udder

Table 3. Herd demographics for the study population $(\mathrm{n}=251)^{1}$

\begin{tabular}{|c|c|c|c|}
\hline Item & Mean & Median & Range $^{2}$ \\
\hline No. of dairy cows/herd & 26.9 & 21 & 8-94 \\
\hline Overall milk yield/cow in $2016(\mathrm{~kg})$ & 8,233 & 8,258 & $2,256-13,246$ \\
\hline Individual cow SCC from milk performance recording every $4-6 \mathrm{wk}$ (cells $/ \mathrm{mL}$ ) & 163,450 & 131,085 & $30,620-2,545,290$ \\
\hline
\end{tabular}

${ }^{1}$ Included in the variable selection process of the generalized linear mixed model.

${ }^{2}$ Minumum to maximum. 


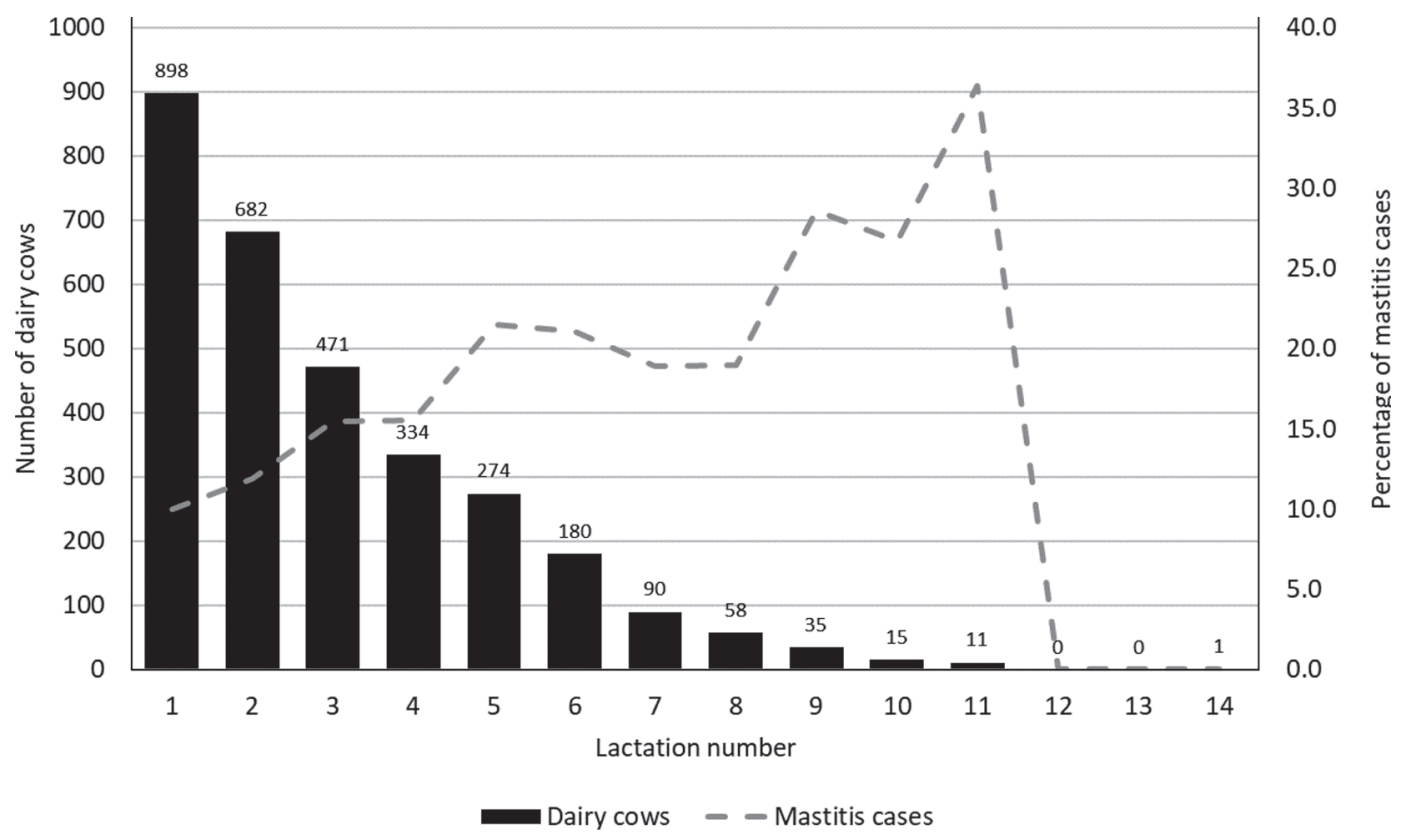

Figure 2. Distribution of dairy cows by lactation number and proportion (\%) of mastitis cases reported.

hygiene), milking machinery and technique (automatic shut-off), and veterinary diagnostics (regular bacteriological milk culture) all significantly influenced the probability of mastitis in this study population. Table 5 lists the results from the GLMM for the fixed effects $\hat{\beta}_{1}, \ldots, \hat{\beta}_{p}$ with $95 \%$ CI and the corresponding $P$-values. Additionally, the odds ratios (OR) and their 95\% CI are shown in relation to the respective reference category.

According to the estimated coefficients for the fixed effects, the estimated coefficient for regular access to pasture $(-0.32)$ indicated an association with a significantly $(P=0.047)$ reduced risk $(\mathrm{OR}=0.73)$ of mastitis for cows that had regular access to pasture compared with those that did not. With regards to milking technique, the use of automatic cluster switch-off on the milking machine had a protective effect, with 0.67 lower odds of mastitis occurring (coefficient $=-0.41, P=$ 0.019 ) when this system was used. Similarly, the model found that cows with access to feed immediately after milking had 0.43 lower odds of mastitis compared with cows with no immediate access (coefficient $=-0.85, P$ $=0.004)$.

With regards to cow age, the odds of mastitis significantly increased with lactation number by a factor of 1.18 (coefficient $=0.17, P<0.001$ ). The probability of mastitis was additionally increased by an OR of 1.55 (coefficient $=0.44, P=0.017$ ) when farmers worked part time on farm and part time elsewhere. An analysis of herd size and working time on farm demonstrated that although there was obviously some correlation between the number of animals on farm and the decision to work full or part time, the inclusion of working time significantly improved the statistical model (with respect to cross-validation) and the inclusion of herd size did not. Although not statistically significant at the $5 \%$ level, the model also determined that when the udders of the herd were heavily soiled before milking, the odds of mastitis occurring increased by a factor of 1.47 (coefficient $=0.38, P=0.062$ ).

The estimated coefficient for regular bacteriological milk culture for mastitis milk (0.43) indicated an as-

Table 4. Farm management factors relating to udder health based on farmer responses $[\text { no. }(\%) ; \mathrm{n}=211]^{1}$

\begin{tabular}{|c|c|c|c|c|}
\hline Survey question & $\begin{array}{l}\text { Regularly/ } \\
\text { all cows }\end{array}$ & $\begin{array}{c}\text { Occasionally/only } \\
\text { symptomatic animals }\end{array}$ & $\begin{array}{l}\text { Never/ } \\
\text { not used }\end{array}$ & $\begin{array}{c}\text { Total of survey } \\
\text { responses }\end{array}$ \\
\hline How often is a bacteriological culture of mastitis milk carried out? & $115(54.5)$ & $83(39.3)$ & $13(6.2)$ & $211(100)$ \\
\hline Are antibiotics routinely used at drying off? & $100(47.4)$ & $109^{2}(51.7)$ & $2(0.9)$ & $211(100)$ \\
\hline Is a bacteriological culture of milk carried out before drying off? & $27(12.8)$ & $147(69.7)$ & $37(17.5)$ & $211(100)$ \\
\hline
\end{tabular}

${ }^{1}$ Included in the variable selection process of the generalized linear mixed model.

${ }^{2}$ Includes both purely symptomatic animals and those with a positive bacteriological culture. 
sociation with a significantly increased risk of mastitis $(\mathrm{OR}=1.53, P=0.008)$ for farms that practiced regular milk testing. The estimated variance component of the random farm effect accounted for 0.45 . This indicates additional (unobserved) characteristics at farm level that influence the probability of mastitis (Table 5).

\section{DISCUSSION}

The study presented here used veterinary medical records to assess whether mastitis occurred during a cow's LP. As antimicrobials to treat mastitis are only available from veterinarians in Austria, it was considered that local herd veterinarians were ideal and reliable sources of this information. The mastitis risk calculated in this study (14.4\%) corresponds to the $14.9 \%$ of dairy cows reported in national animal health data to have experienced at least 1 diagnosis of udder disease over the same period in 2016 (ZuchtData, 2016).

In the GLMM used here, we found that the risk of mastitis increased in association with lactation number (i.e., age), which is to be expected and has been reported by several authors (Busato et al., 2000; Peeler et al., 2002; Taponen et al., 2017). Similarly, another common finding, which was confirmed by our statistical analysis, was that farms on which herd veterinarians assessed the cows' udders as being generally moderately to severely soiled had a tendency for a higher risk of mastitis occurring during the $\mathrm{LP}(\mathrm{OR}=1.47, P=0.062)$ compared with farms on which udders were assessed as clean. A Canadian study determined 1.2 higher odds of elevated SCC in stalls with poor hygiene (DeVries et al., 2012). A further study from the Netherlands showed that the clinical mastitis incidence rate ratio was 0.77 -fold lower when barns were cleaned more than 4 times per day (slatted floors) than when the floor was cleaned less than once per day (Santman-Berends et al., 2016). Similarly, a British study demonstrated that if collecting yards were scraped at least twice daily, then a small protective effect on the mastitis incidence could be determined (rate ratio $=0.90,95 \% \mathrm{CI}=0.84-0.97$, $P=0.01$; Peeler et al., 2000). Although many different factors influence udder cleanliness, Danish studies also found that irrespective of udder health, lactating cows permanently housed in loose housing had an increased risk $(\mathrm{OR}=3.75)$ of dirty hind limbs compared with cows permitted access to pasture, which corresponds with the results determined in the present study with respect to udder soiling (Ellis et al., 2007; Nielsen et al., 2011).

Although the housing systems observed here (tiestalls and freestalls) affect many aspects of milking technique, milking equipment available, and general farm management, these systems were not included in the final stage of the statistical model. One-third of farms included in this study housed their dairy cows in tiestalls, and the remaining two-thirds used a variety of freestall and straw-yard systems. Tethering systems (tiestalls) are often used due to the alpine nature of the mountainous landscape in some regions of Austria; for example, $66.4 \%$ of cattle in Tyrol were reported to be housed in tiestalls in 2010 (Statistik Austria, 2013). In their review of mastitis risk factor studies, Dufour et al. (2011) reported that housing factors are often inconsistent with respect to SCC. However, some studies have reported that tiestalls are associated with higher clinical mastitis rates. For example, a study in the United States determined that cows kept in tiestalls had a 1.5 times greater risk than those housed in freestalls (Richert et al., 2013), confirming a previous Norwegian study (Valde et al., 1997). Nevertheless, this finding was not observed in the current study, although $34 \%$ of

Table 5. Estimated model parameters from the generalized linear mixed model based on 3,049 lactation periods on 208 farms

\begin{tabular}{|c|c|c|c|c|c|c|}
\hline Fixed effect & Data form ${ }^{1}$ & Data source & Coefficient & $95 \% \mathrm{CI}$ & $\begin{array}{l}\text { Odds } \\
\text { ratio }(\mathrm{OR})\end{array}$ & $\begin{array}{l}95 \% \\
\text { CI OR }\end{array}$ \\
\hline Intercept & & & -1.65 & $-2.40,-1.09$ & 0.19 & $0.09,0.34$ \\
\hline Regular access to pasture & Binary $\mathrm{Y} / \mathrm{N}$ & Farmer survey & -0.32 & $-0.66,-0.01$ & 0.73 & $0.52,0.99$ \\
\hline Automatic shut-off & Binary $\mathrm{Y} / \mathrm{N}$ & $\mathrm{NMR}^{2}$ survey & -0.41 & $-0.71,-0.06$ & 0.67 & $0.49,0.94$ \\
\hline $\begin{array}{l}\text { Access to feed immediately } \\
\text { after milking }\end{array}$ & Binary $\mathrm{Y} / \mathrm{N}$ & Farmer survey & -0.85 & $-1.36,-0.17$ & 0.43 & $0.26,0.84$ \\
\hline $\begin{array}{l}\text { Udder hygiene score: } \\
\text { medium to severely soiled }\end{array}$ & Binary Y/N & Veterinarian survey & 0.38 & $-0.02,0.72$ & 1.47 & $0.98,2.06$ \\
\hline$\hat{\sigma}_{\text {farm }}^{2}{ }^{3}$ & & & 0.45 & $0.46,0.80$ & & \\
\hline
\end{tabular}


farms in this study population had tiestalls, which corresponds with findings on Finnish dairy farms, where cows kept in freestalls with automated milking systems or with milking parlors were reported to have a higher estimated SCC than cows kept in tiestalls (Hiitiö et al., 2017).

Overall, herd size $($ median $=21$ cows; mean $=26.9$ cows in this study population) did not appear to have a substantial influence on the probability of mastitis occurring according to the statistical model applied here. This may have been due to the fact that compared with other nations, Austrian dairy farms included in the current study population would all have been classified as small farms, as the maximum number of cows in a herd was 94. Similar findings have been reported in other studies of udder health in small dairy farms. For example, a Finnish study (largest herd size category: $>60$ cows) reported average herd size as having no effect on subclinical mastitis $(\mathrm{OR}=1.003)$, whereas a Swiss study found that a herd size of $>27$ dairy cows and heifers increased the odds of subclinical mastitis occurring compared with smaller herds $(<20$ head; Doherr et al., 2007; Hiitiö et al., 2017). Dairy farms in other European countries often have much larger herds, with surveys from 2016 to 2017 reporting a mean of 61.9 cows per herd in Germany, 93.8 cows per herd in the Netherlands, and 146 cows per herd in the United Kingdom compared with just 21.3 cows per herd in Austria at that time (Barkema et al., 2015; AHDB Dairy, 2018; BMEL Statistik, 2018; CRV, 2018; ZAR, 2018).

In the present study, we found that cows on the farms of part-time farmers (defined as those who derived $<50 \%$ of their household income from the farm) were more likely to suffer from mastitis $(\mathrm{OR}=1.55)$, which is to be expected because these farmers often have less time to observe their animals due to their employment elsewhere. Given the small overall size of Austrian dairy herds, part-time farming is relatively common in this country, as demonstrated by the $28.0 \%$ of parttime farmers enrolled in the current study population, and reported by other Austrian studies, such as 36.2\% of 1,018 respondents as described by Pothmann et al. (2014). A study in the Alpine region of Italy, where small dairy herds (mean $=16.3$ cows in tiestalls) are also common, highlighted that part-time farmers must ensure that they organize their working day efficiently because their time on farm is limited (Poulopoulou et al., 2018).

As modeled here, if bacteriological cultures of mastitis milk were carried out regularly and routinely, then the probability of mastitis occurring appeared to increase statistically significantly $(\mathrm{OR}=1.53, P=$ 0.008). In fact, it is likely that the opposite is actu- ally the case, and it is reasonable to assume that these farms are those with inherent mastitis problems and have increased their testing regimen to improve mastitis detection. Similar results have been reported for freestalls in Switzerland, where the mastitis incidence risk ratio was lower $(0.61, P=0.01)$ when bacteriological cultures were reportedly never done compared with the reference value of always or occasionally done (Gordon et al., 2013) and in a further Swiss study where subclinical mastitis was less likely to occur on farms with a moderate compared with good level of hygiene (Doherr et al., 2007).

Regular access to pasture (reported on $58 \%$ of the farms included here) was found to be a statistically significant protective factor associated with a reduced risk of mastitis (OR $=0.73, P=0.047)$, which corresponds favorably with a German study in heifers where keeping the animals permanently housed increased their odds of developing subclinical mastitis by a factor of 4.86 $(P=0.004$; Krömker et al., 2012). Similarly, a North American study demonstrated an increased prevalence of mastitis in both Holstein and Jersey cows when kept indoors compared with those permitted access to pasture (Washburn et al., 2002). Although not specifying mastitis directly (although high SCC was associated with a higher mortality risk), Burow et al. (2011) determined that access to pasture in Danish dairy cows reduced their overall risk of mortality compared with zero-grazing herds. Explanations for this protective effect have concentrated on the presumably lower level of exposure to environmental pathogens in pastured cows compared with those permanently housed. Several studies have determined that housed cows are more likely to have dirty udders and legs than those at pasture; however, this depends on many factors, such as soil type, climate, and housing management (Ellis et al., 2007; Arnott et al., 2017). Furthermore, as stated above, the GLMM used in the current study also determined that cows on farms where udders were classed as moderately to severely soiled had a tendency for a higher risk of mastitis compared with those classed as clean. It is important to note that there was no statistically significant correlation between cows with access to pasture and those classed as having moderately to severely soiled udders in the present study.

The current study also confirmed the widely accepted view (Tyler et al., 1997; DeVries and von Keyserlingk, 2005; Dufour et al., 2011) that feeding cows immediately after milking (reported on $94 \%$ of study farms) increases cow standing time, allowing more time for the distal teat canal to close, and is likely to reduce the odds of mastitis occurring during the LP - in this case, a 0.43 -fold reduction $(P=0.004)$. This corresponds with a Canadian study that determined similar protec- 
tive odds when cows' postmilking standing time was $>90$ min; namely, an OR of $0.35(95 \% \mathrm{CI}=0.16-0.76$, $P=0.008)$ for increased SCC compared with a baseline of shorter standing times (Watters et al., 2013). These authors also asked whether farmers encouraged postmilking standing by pushing up feed; again, farmers who responded positively to this question were shown to have a protective effect on the odds of developing subclinical mastitis on their farms $(\mathrm{OR}=0.40 ; 95 \%$ CI $=0.18-0.92, P=0.03$; Watters et al., 2013). A Dutch study demonstrated that fixing cows in headlocks after milking (i.e., creating the same effect as feeding immediately after milking by ensuring the animals remain standing) reduced the risk of Streptococcus uberis mastitis occurring by 0.58 -fold (Barkema et al., 1999). A British study also showed a small protective effect of offering feed directly after milking with a rate ratio of 0.90 (95\% CI $=0.84-0.97, P=0.01)$ from questionnaire responses by 1,253 farmers reporting mastitis incidence (Peeler et al., 2000). However, it is important to note that the relationship between standing behavior and udder health is complex and often nonlinear. In the current study, we did not record the length of time spent standing after milking, although previous studies have demonstrated that cows lying down $>40$ to $<60$ min after milking have a lower risk of IMI occurring, whereas those lying down for the first time $>60$ min after milking had an increased risk (DeVries et al., 2010).

An automatic milking machine shut-off (reported to be present on $76 \%$ of farms with milking parlors and $53 \%$ of farms with vacuum pipeline milking) was also found to have a protective effect with respect to mastitis occurrence, reducing the odds of mastitis occurring by 0.67 -fold $(P=0.019)$. Previous studies have demonstrated that ensuring that the vacuum and other technical aspects of the milking machine, such as automatic shut-off and cluster removal systems, are optimized can reduce overmilking and the development of hyperkeratosis lesions on teats (Neijenhuis, 2011; Edwards et al., 2013). Several studies have also shown that teat injuries and lesions can be related to higher SCC and the incidence of clinical mastitis, although this correlation cannot be considered to be unequivocally proven (Neijenhuis et al., 2001; Cerqueira et al., 2018).

Several factors generally considered to be important in the prevention of udder disease, such as the use of teat dip, milking gloves, method of teat cleaning, disinfecting clusters between cows, or using antimicrobials at dry off, were not included in the final statistical GLMM. It is important to note that this does not mean that these factors were not relevant to the probability of mastitis occurring but rather that other factors in- troduced into the GLMM in a stepwise manner had a more substantial influence on this probability.

Although based on a convenience sample and not a randomized population, the distribution of dairy cattle breeds in this study corresponds with national statistics for Austria. According to ZAR (2017), 73.6\% of cows enrolled in the national milk performance recording scheme in 2016 were of the Simmental (Austrian Fleckvieh) breed, with a further $11.5 \%$ of dairy cows being Brown Swiss (Braunvieh) and 11.8\% being Holstein Friesian. This compares favorably with the breed distribution of dairy cows in the current study population, where $73.9 \%$ were Simmental, $10.9 \%$ were Brown Swiss, and $12.7 \%$ were Holstein Friesian. The average annual milk yield over all breeds in Austria is $7,425 \mathrm{~kg}$ (average milk fat $=4.14 \%$, protein $=3.40 \%$; ZAR, 2017) compared with $8,233 \mathrm{~kg}$ in the current study population. The arithmetic mean SCC was 163,450 cells $/ \mathrm{mL}$ (Table 3) compared with the Austrian national average SCC of 171,200 cells/mL in 2016 (ZuchtData, 2016). National figures from the Austrian Marketing Board reported that between October 2015 and September 2016 (the period observed here), on average $87.6 \%$ (range $=82.5-90.8 \%$ ) of liquid milk delivered in Austria was S-class (i.e., had an SCC $<250,000$ cells $/ \mathrm{mL}$ and a bacterial count $<50,000 / \mathrm{mL}$; AgrarMarkt Austria, 2016a, b).

The most recent national data on cattle housing systems in Austria are from 2010. At that time, 42.1\% of cattle were housed in tiestalls, whereas $57.9 \%$ were kept in freestalls or other nontethered systems (Statistik Austria, 2013). As several marketing schemes have since restricted the use of tiestalls in the production of their products, it can be assumed that the proportion of freestalls compared with tiestalls is increasing and that the distribution determined in this study population (namely, $34.1 \%$ tiestalls vs. $65.9 \%$ freestalls and other) is likely comparable with the current Austrian national average. Furthermore, approximately $20 \%$ of the farms included in this study population were organic producers, which corresponds to national figures for the proportion of organic dairy farmers. A total of $19 \%$ of all liquid milk sold in Austria in 2015 was from organically run dairy farms (BMLFUW, 2016), and $20.7 \%$ of all cattle (beef and dairy) were on organic farms in 2017 (BMLFUW, 2017).

\section{CONCLUSIONS}

Overall, the study presented here provides muchneeded data on the risk factors for mastitis on small dairy farms, which are typical for this Alpine region of Central Europe. Although many studies have been 
carried out in large dairy herds, small mountain family farms are a completely different type of production system. Based on the results of the GLMM applied here, recommendations can be made to allow cows on such farms regular access to pasture, to feed cows immediately after milking, and to use milking machinery with automatic shut-off systems. This statistical model also determined that farmers should ensure that they have sufficient time to provide adequate animal husbandry (i.e., run farms as a full-time enterprise); however, it is important to realize that social and economic pressures may prevent this. Overall, as mastitis is a multifactorial disease, such recommendations can never be taken as individual measures but rather must be implemented as part of an integrated udder health program and take all aspects of farm management into account.

\section{ACKNOWLEDGMENTS}

The authors thank all veterinarians and dairy farmers who agreed to participate in the ADDA-Advancement of Dairying in Austria project, without whom this study would not have been possible. The K-Projekt ADDA-Advancement of Dairying in Austria was supported by the Bundesministerium für Verkehr, Innovation und Technologie (BMVIT, Vienna, Austria), Bundesministerium für Wirtschaft, Familie und Jugend (BMWFJ, Vienna, Austria), the province of Lower Austria, and the city of Vienna in the framework of COMET - Competence Centers for Excellent Technologies. The COMET program was handled by the Österreichische Forschungsförderungsgesellschaft (FFG, Vienna, Austria).

\section{REFERENCES}

AgrarMarkt Austria. 2016a. Qualitätsergebnisse Der Anlieferungsmilch Österreich (Results of the Quality Assessment of Delivered Liquid Milk in Austria). Accessed Jul. 30, 2018. https://www .ama.at/getattachment/0d6f9f20-f0e3-4ceb-b017-9410465596e6/11 _Marktbericht_Milch_Milchprodukte_11_2015.pdf.

AgrarMarkt Austria. 2016b. Qualitätsergebnisse Der Anlieferungsmilch Österreich 2016 (Results of the Quality Assessment of Delivered Liquid Milk in Austria 2016). Accessed Jul. 30, 2018. https://www .ama.at/getattachment/b2778d24-40d7-43bb-88e0-01df6b5f5672/ 08_Marktbericht_Milch_Milchprodukte_08_2016.pdf.

AHDB Dairy. 2018. Average herd size. Accessed Nov. 28, 2018. https:/ /dairy.ahdb.org.uk/resources-library/market-information/farming -data/average-herd-size/\#.W_6dPoXeNq0.

Arnott, G., C. P. Ferris, and N. E. O'Connell. 2017. Review: Welfare of dairy cows in continuously housed and pasture-based production systems. Animal 11:261-273. https://doi.org/10.1017/ S1751731116001336.

Barkema, H. W., Y. H. Schukken, T. J. Lam, M. L. Beiboer, G. Benedictus, and A. Brand. 1999. Management practices associated with the incidence rate of clinical mastitis. J. Dairy Sci. 82:1643-1654. https://doi.org/10.3168/jds.S0022-0302(99)75393-2.

Barkema, H. W., M. A. G. von Keyserlingk, J. P. Kastelic, T. J. G. M. Lam, C. Luby, J.-P. Roy, S. J. LeBlanc, G. P. Keefe, and D. F. Kelton. 2015. Invited review: Changes in the dairy industry af- fecting dairy cattle health and welfare. J. Dairy Sci. 98:7426-7445. https://doi.org/10.3168/jds.2015-9377.

Bates, D., M. Mächler, B. Bolker, and S. Walker. 2015. Fitting linear mixed-effects models using lme4. J. Stat. Softw. 67:1-48. https:// doi.org/10.18637/jss.v067.i01.

BMEL Statistik. 2018. Betriebe mit Milchkuhhaltung nach Bestandsgrößenklassen. Accessed Nov. 28, 2018. http://www.bmel-statistik .de/de/landwirtschaft/statistischer-monatsbericht-des-bmel -kapitel-a-landwirtschaft/.

BMLFUW (Bundesministerium für Land- und Forstwirtschaft, Umwelt und Wasserwirtschaft). 2016. Grüner Bericht 2016: Bericht über die Situation der Österreichischen Land- und Forstwirtschaft im Jahr 2016 (Green Report 2016: Report on the Situation in Austrian Agriculture and Forestry in 2016). Vienna, Austria. https: //gruenerbericht.at/cm4/jdownload/send/2-gr-bericht-terreich/ 1650-gb2016.

BMLFUW (Bundesministerium für Land- und Forstwirtschaft, Umwelt und Wasserwirtschaft). 2017. Grüner Bericht 2017: Bericht über die Situation der Österreichischen Land- und Forstwirtschaft im Jahr 2017 (Green Report 2017: Report on the Situation in Austrian Agriculture and Forestry in 2017). Vienna, Austria. https: //gruenerbericht.at/cm4/jdownload/send/2-gr-bericht-terreich/ 1773-gb2017.

Burow, E., P. T. Thomsen, J. T. Sørensen, and T. Rousing. 2011. The effect of grazing on cow mortality in Danish dairy herds. Prev. Vet. Med. 100:237-241. https://doi.org/10.1016/j.prevetmed.2011 .04 .001 .

Busato, A., P. Trachsel, M. Schällibaum, and J. W. Blum. 2000. Udder health and risk factors for subclinical mastitis in organic dairy farms in Switzerland. Prev. Vet. Med. 44:205-220. https://doi.org/ 10.1016/S0167-5877(00)00104-5.

Cerqueira, J. L., J. P. Araújo, and J. Cantalapiedra. 2018. How is the association of teat-end severe hyperkeratosis on udder health and dairy cow behavior? Rev. Med. Vet. 169:30-37.

Corazzin, M., E. Piasentier, S. Dovier, and S. Bovolenta. 2010. Effect of summer grazing on welfare of dairy cows reared in mountain tie-stall barns. Ital. J. Anim. Sci. 9:304-312. https://doi.org/10 $.4081 /$ ijas.2010.e59.

CRV. 2018. Melkproductieregistratie/Milk Recording. Accessed Nov. 28, 2018. https://crvnl-be6.kxcdn.com/wp-content/uploads/2018/ 03/Totaal-Jaarstatistieken-2017-NL.pdf.

DeVries, T. J., M. G. Aarnoudse, H. W. Barkema, K. E. Leslie, and M. A. G. von Keyserlingk. 2012. Associations of dairy cow behavior, barn hygiene, cow hygiene, and risk of elevated somatic cell count. J. Dairy Sci. 95:5730-5739. https://doi.org/10.3168/ jds.2012-5375.

DeVries, T. J., S. Dufour, and D. T. Scholl. 2010. Relationship between feeding strategy, lying behavior patterns, and incidence of intramammary infection in dairy cows. J. Dairy Sci. 93:1987-1997. https://doi.org/10.3168/jds.2009-2692.

DeVries, T. J., and M. A. G. von Keyserlingk. 2005. Time of feed delivery affects the feeding and lying patterns of dairy cows. J. Dairy Sci. 88:625-631. https://doi.org/10.3168/jds.S0022-0302(05)72726 -0 .

Doherr, M. G., M. Roesch, W. Schaeren, M. Schallibaum, and J. W. Blum. 2007. Risk factors associated with subclinical mastitis in dairy cows on Swiss organic and conventional production system farms. Vet. Med. (Praha) 52:487-495. https://doi.org/10.17221/ 2060-VETMED.

Dufour, S., A. Fréchette, H. W. Barkema, A. Mussell, and D. T. Scholl. 2011. Invited review: Effect of udder health management practices on herd somatic cell count. J. Dairy Sci. 94:563-579. https://doi .org/10.3168/jds.2010-3715.

Edwards, J. P., B. O’Brien, N. Lopez-Villalobos, and J. G. Jago. 2013. Overmilking causes deterioration in teat-end condition of dairy cows in late lactation. J. Dairy Res. 80:344-348. https://doi.org/ $10.1017 /$ S0022029913000307.

Egger-Danner, C., B. Fürst-Waltl, W. Obritzhauser, C. Fürst, H Schwarzenbacher, B. Grassauer, M. Mayerhofer, and A. Koeck. 2012. Recording of direct health traits in Austria - Experience report with emphasis on aspects of availability for breeding purpos- 
es. J. Dairy Sci. 95:2765-2777. https://doi.org/10.3168/jds.2011 -4876 .

Ellis, K. A., G. T. Innocent, M. Mihm, P. Cripps, W. G. McLean, C. V. Howard, and D. Grove-White. 2007. Dairy cow cleanliness and milk quality on organic and conventional farms in the UK. J. Dairy Res. 74:302-310. https://doi.org/10.1017/S002202990700249X.

Firth, C. L., A. Käsbohrer, C. Schleicher, K. Fuchs, C. Egger-Danner, M. Mayerhofer, H. Schobesberger, J. Köfer, and W. Obritzhauser. 2017. Antimicrobial consumption on Austrian dairy farms: An observational study of udder disease treatments based on veterinary medication records. PeerJ 5:e4072. https://doi.org/10.7717/peerj .4072 .

Fox, J., and S. Weisberg. 2011. An R Companion to Applied Regression. 2nd ed. Sage, Thousand Oaks, CA.

Gile, K. J., and M. S. Handcock. 2010. Respondent-driven sampling: An assessment of current methodology. Sociol. Methodol. 40:285327. https://doi.org/10.1111/j.1467-9531.2010.01223.x.

Gordon, P. F., B. H. P. van den Borne, M. Reist, S. Kohler, and M. G. Doherr. 2013. Questionnaire-based study to assess the association between management practices and mastitis within tie-stall and free-stall dairy housing systems in Switzerland. BMC Vet. Res. 9:200. https://doi.org/10.1186/1746-6148-9-200.

Hastie, T., R. Tibshirani, and J. Friedman. 2009. The Elements of Statistical Learning: Data Mining, Inference, and Prediction. 2nd ed. Springer, Berlin, Germany.

Hiitiö, H., J. Vakkamäki, H. Simojoki, T. Autio, J. Junnila, S. Pelkonen, and S. Pyörälä. 2017. Prevalence of subclinical mastitis in Finnish dairy cows: Changes during recent decades and impact of cow and herd factors. Acta Vet. Scand. 59:22. https://doi.org/10 .1186/s13028-017-0288-x.

Krömker, V., F. Pfannenschmidt, K. Helmke, R. Andersson, and N. T. Grabowski. 2012. Risk factors for intramammary infections and subclinical mastitis in post-partum dairy heifers. J. Dairy Res. 79:304-309. https://doi.org/10.1017/S0022029912000222.

Neave, F. K., F. Dodd, and R. Kingwill. 1966. A method of controlling udder disease. Vet. Rec. 78:521-523. https://doi.org/10.1136/ vr.78.15.521.

Neijenhuis, F. 2011. Mastitis therapy and control-Role of milking machines in control of mastitis. Pages 440-446 in Encyclopedia of Dairy Sciences. 2nd ed. J. W. Fuquay, ed. Elsevier, Wageningen, the Netherlands.

Neijenhuis, F., H. W. Barkema, H. Hogeveen, and J. P. T. M. Noordhuizen. 2001. Relationship between teat-end callosity and occurrence of clinical mastitis. J. Dairy Sci. 84:2664-2672. https://doi .org/10.3168/jds.S0022-0302(01)74720-0.

Nielsen, B. H., P. T. Thomsen, and J. T. Sørensen. 2011. Identifying risk factors for poor hind limb cleanliness in Danish loosehoused dairy cows. Animal 5:1613-1619. https://doi.org/10.1017/ S1751731111000905.

Peeler, E. J., M. J. Green, J. L. Fitzpatrick, and L. E. Green. 2002. Study of clinical mastitis in British dairy herds with bulk milk somatic cell counts less than 150,000 cells/mL. Vet. Rec. 151:170176. https://doi.org/10.1136/vr.151.6.170.

Peeler, E. J., M. J. Green, J. L. Fitzpatrick, K. L. Morgan, and L. E. Green. 2000. Risk factors associated with clinical mastitis in low somatic cell count British dairy herds. J. Dairy Sci. 83:2464-2472. https://doi.org/10.3168/jds.S0022-0302(00)75138-1.

Pothmann, H., K. Nechanitzky, F. Sturmlechner, and M. Drillich. 2014. Consultancy to dairy farmers relating to animal health and herd health management on small- and medium-sized farms. J. Dairy Sci. 97:851-860. https://doi.org/10.3168/jds.2013-7364.

Poulopoulou, I., M. C. Nock, S. Steinmayer, C. Lambertz, and M. Gauly. 2018. How can working time analysis contribute to the production efficiency of dairy farms in mountain regions? Ital. J.
Anim. Sci. 17:489-498. https://doi.org/10.1080/1828051X.2017 .1363638 .

R Core Team. 2016. A Language and Environment for Statistical Computing. Accessed Aug. 13, 2018. https://www.r-project.org.

Richert, R. M., K. M. Cicconi, M. J. Gamroth, Y. H. Schukken, K. E. Stiglbauer, and P. L. Ruegg. 2013. Risk factors for clinical mastitis, ketosis, and pneumonia in dairy cattle on organic and small conventional farms in the United States. J. Dairy Sci. 96:42694285. https://doi.org/10.3168/jds.2012-5980.

Santman-Berends, I. M. G. A., J. M. Swinkels, T. J. G. M. Lam, J. Keurentjes, and G. van Schaik. 2016. Evaluation of udder health parameters and risk factors for clinical mastitis in Dutch dairy herds in the context of a restricted antimicrobial usage policy. J. Dairy Sci. 99:2930-2939. https://doi.org/10.3168/jds.2015-10398.

Schabauer, A., B. Pinior, C.-M. Gruber, C. L. Firth, A. Käsbohrer, M. Wagner, K. Rychli, and W. Obritzhauser. 2018. The relationship between clinical signs and microbiological species, spa type, and antimicrobial resistance in bovine mastitis cases in Austria. Vet. Microbiol. 227:52-60. https://doi.org/10.1016/j.vetmic.2018 .10.024.

Statistik Austria. 2013. Haltungsverfahren für Rinder 2010 (Cattle Housing Systems 2010). Accessed Nov. 29, 2018. https://www.statistik .at/web_de/statistiken/wirtschaft/land_und_forstwirtschaft/ agrarstruktur_flaechen_ertraege/betriebsstruktur/index.html.

Taponen, S., E. Liski, A.-M. Heikkilä, and S. Pyörälä. 2017. Factors associated with intramammary infection in dairy cows caused by coagulase-negative staphylococci, Staphylococcus aureus, Streptococcus uberis, Streptococcus dysgalactiae, Corynebacterium bovis, or Escherichia coli. J. Dairy Sci. 100:493-503. https://doi.org/10 .3168/jds.2016-11465.

Tyler, J. W., L. K. Fox, S. M. Parish, J. Swain, D. L. Johnson, H. A. Grasseschi, and R. Gant. 1997. Effect of feed availability on postmilking standing time in dairy cows. J. Dairy Res. 64:617-620. https://doi.org/10.1017/S0022029997002501.

Valde, J. P., D. W. Hird, M. C. Thurmond, and O. Osterås. 1997. Comparison of ketosis, clinical mastitis, somatic cell count, and reproductive performance between free stall and tie stall barns in Norwegian dairy herds with automatic feeding. Acta Vet. Scand. 38:181-192.

van Soest, F. J. S., I. M. G. A. Santman-Berends, T. J. G. M. Lam, and H. Hogeveen. 2016. Failure and preventive costs of mastitis on Dutch dairy farms. J. Dairy Sci. 99:8365-8374. https://doi.org/10 $.3168 /$ jds.2015-10561.

Washburn, S. P., S. L. White, J. T. Green Jr., and G. A. Benson. 2002. Reproduction, mastitis, and body condition of seasonally calved Holstein and Jersey cows in confinement or pasture systems. J. Dairy Sci. 85:105-111.

Watters, M. E. A., K. M. A. Meijer, H. W. Barkema, K. E. Leslie, M. A. G. von Keyserlingk, and T. J. DeVries. 2013. Associations of herd- and cow-level factors, cow lying behavior, and risk of elevated somatic cell count in free-stall housed lactating dairy cows. Prev. Vet. Med. 111:245-255. https://doi.org/10.1016/j.prevetmed 2013.05.015.

ZAR (Federation of Austrian Cattle Breeders). 2017. ZAR Jahresbericht 2016 (Federation of Austrian Cattle Breeders-Annual Report 2016). Vienna, Austria. Zentrale Arbeitsgemeinschaft österreichischer Rinderzüchter.

ZAR (Federation of Austrian Cattle Breeders). 2018. ZAR Jahresbericht 2017 (Federation of Austrian Cattle Breeders-Annual Report 2017). Vienna, Austria. Zentrale Arbeitsgemeinschaft österreichischer Rinderzüchter.

ZuchtData. 2016. Kennzahlenbericht zur Tiergesundheit Rind 2016 (Report on Key Performance Indicators for Animal Health: Cattle 2016). Vienna, Austria. ZuchtData EDV Dienstleistungen GmbH. 